\title{
Phatic Advice Giving of Javanese Youngsters in Friendship Domain as A Politeness Strategy to Tie A Union
}

\author{
Yuli Widiana \\ Department of Linguistics \\ Universitas Sebelas Maret \\ Surakarta, Indonesia \\ widianayuli@student.uns.ac.id \\ Sri Marmanto \\ Universitas Sebelas Maret \\ Surakarta, Indonesia \\ marmanto@staff.uns.ac.id
}

\author{
Sumarlam \\ Universitas Sebelas Maret \\ Surakarta, Indonesia \\ sumarlam@staff.uns.ac.id \\ Dwi Purnanto \\ Universitas Sebelas Maret \\ Surakarta, Indonesia \\ dwi.purnanto@yahoo.com
}

\begin{abstract}
Javanese speech community is culturally a collective society. Togetherness to maintain a social bond could be performed by giving phatic advice as the expression of sympathy by applying Javanese politeness principles (Gunarwan, 2007). Kinds and strategies of giving phatic advice in Javanese youngsters are the focus of this research. The method of collecting data for this research is distributing Discourse Completion Tasks (DCT) to 100 respondents. Then, in-depth interview with the informants is conducted as well to verify the data from the DCT. The respondents and the informants are university students in Madiun who are the native speakers of Javanese. The result of the research shows that the kinds of phatic advice are suggestion, prohibition, and support with peculiar characteristics which are different from the characteristics of a directive speech act of the previous theories (Searle, 1969, Kreidler 1998). The strategies of giving phatic advice consist of reassuring, complimenting, encouraging, stating common things, sharing common experiences, warning, and insinuating. Apparently, the act of advice giving in Javanese youngsters community is not mainly intended to give a problem solving but more about showing politeness by expressing sympathy. Therefore, the advice giving is categorized as phatic as it only performs to maintain social relationship and friendship among the members of the society. Consolation is the main feature of phatic advice giving in Javanese culture.
\end{abstract}

Keywords-phatic; advice giving; Javanese students; consolation; politeness

\section{INTRODUCTION}

Creating a social relationship is a basic need of human beings as social creatures. Conducting phatic communication is one way to perform a social relationship. Phatic speech act is defined by Malinowski (1923) as a type of speech in which ties of union are created by a mere exchange of words. Moreover, he also introduced the terms of 'phatic communion'. Phatic speech act may be performed in the form of advice giving. Hence, one of the categories of advice in Javanese culture is phatic advice. Unlike the act of giving advice which is included into directive speech act, phatic advice is not intended to make people do something based on our suggestion or advice. The main goal is just to console people from the trouble they face. Therefore, the kinds and the strategies of phatic advice in Javanese culture are the focus of this research.

Basically, phatic advice is used to give attention to each other in order to maintain a social relationship among members of such a speech community. Thus, the advice is only used to perform hospitality and friendship. This phenomenon is found among the Javanese students in Madiun, East Java Province, Indonesia. Intimacy and camaraderie are very important to create a friendship atmosphere among them so that giving attention to each other is a crucial thing to maintain friendship. Yet, giving attention may be performed by giving advice to a friend who faces a problem as an expression of empathy and sympathy.

Some strategies in conducting phatic advice giving are influenced by the factors of 'Power' and 'Distance'. Consequently, the strategy to give phatic advice which is used by speakers and hearers who are closed to each other will be different from the strategy used by those who are not closed. Hence, the strategies depend on social distance which is related to the degree of intimacy among the participants.

Phatic communication in Javanese culture is such an important strategy to show hospitality in order to be accepted as a member of Javanese community. Javanese is expected to have a good personality which is known as Grapyak 'Friendly' and Semanak 'Warm' (Poerwadarminta 1939). Thus, to be friendly and warm, one must be easily connected to each other by performing phatic speech act, i.e greeting, small talks, saying well-wishes, consoling others, etc. Then, to avoid conflict in performing phatic speech act, Javanese is urged to pay much attention to politeness maxims such as Kurmat 'Respect', Andhap Asor 'Being humble', Tepa Selira 'Being tolerant', and Empan Papan 'Self awareness' (Gunarwan 2007). The similar strategy is seen in the act of advice giving in American culture which is commonly performed indirectly to reduce the Face Threatening Act 
(FTA) towards hearers (DeCapua and Dunham 2007; AlShboul, Maros and Yasin 2012; Tsai and Kinginger 2014). However, the intention of advice giving in American culture is mainly to offer acounseling for a problem solving whereas not all advice in Javanese culture contain a problem solving. Some advices are merely for consoling others. These kinds of advices are categorized as phatic advice.

The fact that phatic communication is the essential thing in Javanese social relationship is obviously different from the function of phatic communication in other culture. In Norwegian culture, for instance, other politeness markers are more important than phatic talk. Hence, there are other ways to show politeness, and they are linked to terms such as privacy, leaving others alone and respecting their integrity, keeping a certain distance until you are invited in, not being a nuisance not beingimportunate and not to bother others (Rygg 2016).

Since phatic communication is very important in Javanese culture, this research is aimed to reveal the phenomenon of phatic advice among Javanese youngsters as one kind of phatic speech act. Hence, the importance of phatic advice giving is discussed in this research by applying pragmatic approach.

The result of this research may contribute the valuable topic for teaching materials of Javanese language and culture in elementary schools, high schools, and higher education institutions. Thus, the research may contribute the topics for the Ministry of Research, Technology, and Higher Education and the Ministry of National Education in arranging the national curriculum of cultural teaching for elementary school, high school and universities.

\section{LITERATURE REVIEW}

The act of advice giving is universal. However, previous research proves that sociopragmatic rules and norms in conducting advice giving speech act which build realization of appropriate speech act is various in each culture and language (Kasper and Blum-Kulka 1993; Wierzbicka 2009; DeCapua and Dunham 2007). Therefore, the act of phatic advice giving in Javanese culture has peculiar characteristics which are not found in other culture.

Previous study which discussed directive speech act of advice giving is conducted DeCapua and Dunham (2007). The research is about the pattern of advice giving of English native speakers and Non-native speakers of English in the letters published in printed media. The result shows that there are some cultural differences in the pattern of advice giving. English native speakers use imperative sentences in giving advice which is considered as a weak imperative illocution as the information which is given is more like a form of counseling than imperative or imposition towards hearers. Imperative phrases 'be honest', 'keep in mind', and 'try to focus on' which are used for counseling may reduce the imperative force. Moreover, English native speakers use longer narrative form. On the contrary, DeCapua and Dunham (2007) found that Non-native English speakers tend to give shorter advice. Reducing imperative power is one of the characteristics of phatic advice in Javanese culture as well.
Tsai and Kinginger (2014) conducted another research of advice giving speech act. The focus is the advice giving in computer media interactions. The findings shows that the critic expressed by hearers tend to be suppressed by the advice givers by giving them compliments instead of giving advice directly in order to maintain harmonious interpersonal relationship. Maintaining harmony in a relationship is also the essential thing in the act of phatic advice giving in Javanese culture.

Furthermore, strategies of advice giving speech act are one of the focuses of the previous studies. Al-Shboul, Maros, and Yasin (2012) in their research towards American-English native speakers and Jordanian learners of English as a foreign language find that direct advice and hedge advice are the best strategies for a peer acquaintance and an instructor in Jordanian culture whereas American culture considers that the strategies are not appropriate.

The next research of advice giving strategy conducted by Farashaiyan (2016) towards Malaysian learners of English in different situational context proves that Malaysians tend to choose direct strategy which is classified into obligation strategy, mood derivable strategy, and performative strategy.

None of the previous studies of advice giving speech act discusses about advice giving in phatic function. Therefore, this research introduces a breakthrough point of view about the phaticity of advice giving for social interrelationship.

\section{Advice Giving Speech Act}

Theoretical reviews of advice giving is taken from the theory of directive speech act which is introduced by Searle (1969). Directive speech act is the effort of speakers to make hearers do something based on the speakers' will. In the next taxonomy, the concept of directive speech act is classified into commands, requests, and suggestions (Kreidler 1998). In this classification, advice is a part of suggestions. The act of giving suggestion aims to give opinion to hearers about what to do or not to do. Thus, the act of advice giving contains problem solving that is expected to be done by the hearers.

In Javanese culture, not all advice giving is a directive speech act. The act of advice giving may be phatic as it does not contain any specific information or instruction to share. Thus, it fulfills the characteristics of phatic talk as a conversation to break the silence as a minimum effort to fulfil the basic requirement of communication (Coupland 2014, 2). In other words, phatic advice is mainly the act of expressing sympathy and camaraderie.

\section{Politeness Principles}

The act of advice giving is related to politeness which is specific in each culture. What is considered to be polite or impolite lies more on hearers' perception than speakers' intention. To this extent, speakers perform polite behavior in order to maintain a good relationship with hearers in such a social interaction.

The concept of being polite in Javanese culture is related to politeness principles proposed by Asim Gunarwan (2007) which is derived from Javanese philosophy of creating a balance of physical and spiritual life. Gunarwan formulated four Javanese politeness maxims which consist of kurmat 'Respect', andhap-asor 'Being humble', empan papan 'Self awareness', and tepa-selira 'Being tolerant'. The four maxims 
are applied in the act of phatic advice giving in Javanese culture.

The previous theory of politeness strategies is proposed by Leech (1983) who classifies the strategies into irony, banter, hedge, and phatic. The theory is related to his politeness theory which is known by 'General Strategy of Politeness' (GSP) with its ten maxims (Leech, 2014).

The more specific strategy of advice giving speech act is formulated by Blum-Kulka et al (1989). They divided the taxonomy of the strategy of advice giving into two main parts, direct strategy and indirect strategy. Direct strategy consists of five specific strategies, (1) imperatives, (2) performatives, (3) Hedged performatives, (4) Obligation, (5) Desire. Indirect strategy is classified into two kinds, conventional indirect strategy and non-conventional indirect strategy. Conventional strategy consists of (1) suggestion formula, (2) preparatory condition. Then, non-conventional strategy consists of (1) strong hints and (2) soft hints. The act of phatic advice giving applies some peculiar strategies which are different from other culture.

\section{METHOD}

This research is a qualitative research which uses empirical method. The problems are analyzed by using qualitative approach in which the researcher observes, understands, arranges, classifies or categorizes, relates the categories, and interpretes the data based on the context (Santosa, 2017). In this case, the data of phatic advice is classified into several kinds based on the context where they occur.

To get the appropriate data, purposive sampling technique is applied in this research. To this extent, criteria to obtain samples that are appropriate for the research must be determined first. Thus, criterion-based sampling which is determined by considering some aspects such as background description, events, people, behavior and its interaction (Patton 1980) is applied.

The source of data of the research is Javanese students in Madiun. The criteria are 1) native speakers of Javanese; 2) Age is between 17 to 30 years old; 3) Living in Javanese environment since their birth; 4) University students. Five top universities in Madiun are chosen to obtain the data.

The data of this research are utterances which contain phatic advice giving. It fulfills the characteristics of data in pragmatics research which are always in the form of utterances including their contexts that may be taken from text that could be orally or written as the focus in pragmatics research is the study of speech act realization in various speech situations in relation to various kinds of pragmatic aspects (Subroto 2008; Jumanto 2011; Leech, 2014).

Data from respondents are elicited by distributing Discourse Completion Test (DCT) to 110 respondents. The DCT is an open questionnaire which consists of 10 questions in 10 different speech situations. Open questionnaire is considered to be more effective to obtain the more natural data which reflect the reality. Next, the data taken from the DCT is verified by the technique of in-depth interview. Hence, 5 informants are selected to be interviewed to get the verification of the data from the DCT.

To analyze the kinds of phatic advice, the data are classified through the steps introduced by Spradley (2016).
The steps are started by the identification of domain. Next, the data are classified into the more specific category to construct a taxonomy. Then, the relation of each sub-category is analyzed by componential analysis. The result is cultural theme of the characteristics of phatic advice among Javanese youngsters. Furthermore, contextual method (Djajasudarma 2012) is applied in this research to scrutinize the strategies of phatic advice giving among Javanese youngsters.

\section{RESUlT AND DisCUSSION}

\section{A. Result}

The findings of the research are divided into the kinds of phatic advice and the strategies which are used to perform them. Each kind of phatic advice is explained further by using some data taken from DCT. Meanwhile, the strategies of the realization of phatic advice giving are explained by the contextual method.

\section{1) The Kinds of Phatic Advice}

Phatic advice is classified into support, suggestion, and prohibition. Support contains utterances to encourage people to do good things whereas suggestions are things recommended by speakers to hearers. Phatic advice may also in the form of prohibition in which speakers warn hearers not to do something.. The following table describes the kinds of phatic advice.

TABLE I.

\begin{tabular}{|l|c|}
\hline \multicolumn{1}{|c|}{ Kinds } & Percentage of Occurence \\
\hline Support & $42.73 \%$ \\
\hline Suggestion & $32.73 \%$ \\
\hline Prohibition & $24.54 \%$ \\
\hline Total & $\mathbf{1 0 0 \%}$ \\
\hline
\end{tabular}

Phatic advice in the category of support is mostly found whereas prohibition is the least. Javanese politeness principles Tepa Selira 'Tolerant' is the trigger of giving support to the ones who face a problem. The realization of being tolerant, showing empathy and expressing sympathy may be expressed by giving support. It plays an important role to maintain a social bond among the Javanese youngsters. On the other hand, the category of prohibition is not as popular as support as it could potentially lead to Face Threatening Act (FTA). Insulting others is mainly avoided, as Javanese considers Rasa 'Feeling' in dealing with others. Hence, suppressing feeling is urged to do in order to maintain a harmonious relationship. In this case, prohibiting ones to do something would potentially insult them.

The category of support is identified by the use of some linguistic forms such as Wis ta 'It is okay', Gak usah khawatir 'Don't worry', Semangat 'Don't give up', sing sabar 'Be patient', tenang wae 'Calm down'. Phatic support are merely used to console others.

Phatic advice may also contain suggestion. However, the suggestions do not really contain a problem solving. The content is mostly common things and common experiences which could happen to everybody. Thus, the phatic

Sponsored by Indonesia Endowment Fund for Education (LPDP RI) 
suggestions do not give any specific way to solve one's peculiar problem.

Prohibition in phatic advice is identified by the occurrence of some linguistic forms like Aja 'Don't', Aja ngono 'Don't do that', Gak oleh 'Not allowed', Gak apik 'Not good'. Furthermore, prohibition which is performed by insinuation may contain mockery and jokes such as Gak isin ta kowe wis tuwek isih nyonto 'Shame on you as you are too old to cheat', Woo maling kuwi jenenge nek nyilih ora mbalekno 'It's called a thief if you borrow something and never give it back'. However, the mockery is delivered in a fun way so that it could avoid FTA.

\section{The Srategies of Phatic Advice Giving}

Javanese politeness principles play a great role in determining the strategies of advice giving speech act. The strategies of phatic advice giving are summarized in the following table.

TABLE II.

\begin{tabular}{|l|l|}
\hline \multicolumn{1}{|c|}{ Kinds } & \multicolumn{1}{c|}{ Strategies } \\
\hline Support & $\begin{array}{l}\text { Reassuring, Complimenting, } \\
\text { Encouraging }\end{array}$ \\
\hline Suggestion & $\begin{array}{l}\text { Stating common things, Sharing } \\
\text { common experiences }\end{array}$ \\
\hline Prohibition & Warning, Insinuating \\
\hline
\end{tabular}

Advice which is performed by giving support may be phatic if the support is merely intended to console someone by reassuring, complimenting, and encouraging. The phatic support may also be uttered mainly to show politeness when the hearer asks for advice and the speaker is reluctant to give advice. To this extent, phatic advice is given to avoid FTA as refusal to do such a thing may potentially insult the hearer. The following datum taken from DCT is the example of encouraging strategy.

Situation: You are a university student. One of your classmates finds difficulty in his study. You want to console your friend by giving him/her advice about the effective way to study in university. What will you say to your friend?

Semangat ta. Tinggal sak semester maneh. Mosok kowe arep nyerah? Isa gak isa kudu dilakoni. Kuat ora kuat kudu lulus.

'Don't give up. It's only one semester to go. You should not give up. No matter how hard it is, you should keep going on. No matter how hard it is, you must finish your study.'

In this case, support is given to make someone strong. Moreover, giving support is also the realization of expressing camaraderie between friends. The advice is phatic as it does not contain any specific suggestion how to study effectively in university.

Phatic advice in the form of suggestion could be conducted by stating common things and sharing common experiences. Hence, the suggestion does not really contain a problem solving. Yet, it is only the statement of what usually happen to everyone. Sharing experiences which are known by both speaker and hearer is another strategy in giving suggestion as a phatic advice. The following DCT is taken for the example. Situation: Your friend has a problem of arranging his/her time to study and to do some other activities. What advice that you will give to your friend to be able to arrange his/her time?

Dibagi wektune. Nek perlu nggawe catetan harian sing isine jadwalmu.

'Arrange your time. If it is necessary, you can make your daily schedule.'

The suggestion is phatic as it does not explain in detail how to arrange the time proportionally between studying and doing other activities. Moreover, the suggestion is a common thing that everybody usually does.

Prohibition may be performed by warning and insinuating. Warning potentially produces FTA. To reduce the risk of performing FTA, insinuating is another strategy which is softer than warning. To this extent, insinuating is such a kind of indirect warning to prevent someone to do negative things. The following datum taken from DCT contains prohibition.

Situation: You have a classmate who likes to cheat in the test. You want to advise him that it is a bad habit. What will you say to your friend to stop cheating?

Aja ngono. Kuwi gak apik.

'Don't do that. It's not good.'

As the prohibition does not contain explanation why cheating is not good, it is considered as phatic. The prohibition is uttered in brief in order not to insult the hearer more.

Prohibition which is conducted by the strategy of insinuating is the alternative way to prohibit one to do negative things. The example is as follows:

Situation: Your friend always borrows things from others and never give them back on time. What advice will you give to stop your friend from continuing the bad habit?

Nyilih ya nyilih tapi aja digawa terus Bos.

'Keep on borrowing it but don't keep it forever.'

Insinuation is used to make ones realize from what they have done. Apparently, an insinuation is softer than a warning. Therefore, Javanese youngsters like to use insinuation to give advice which contains prohibition. Moreover, insinuation may contain a joke which could reduce the FTA. Some jokes are phatic as they are very common just like greetings.

\section{B. Discussion}

The phenomenon of phatic advice among Javanese youngsters proves that advice may be phatic as it is not intended to solve a problem. The previous theory of phatic utterances proposed by Kreidler (1998) does not include advice giving as a part of phatic utterances. Moreover, the previous theories of advice giving speech act (Searle 1969; Kreidler 1998) define that advice giving is directive speech act. None of the earlier theories define that advice giving could be phatic. Thus, this research is a breakthrough point of view in the theory of speech act.

Phatic advice is classified into support, suggestion, and prohibition. The kinds of phatic advice which consist of support, suggestion, and prohibition are performed by using 
peculiar strategies in relation to Javanese politeness principles. The strategies of reassuring, complimenting, and encouraging in phatic support is the reflection of Rasa 'feeling'. In this case, Javanese youngsters express their sympathy and solidarity by supporting each other although the support does not contain any information as a problem solving. It is different from the research of the letters published in printed media conducted by DeCapua and Dunham (2007) which shows that English native speakers give advice which contains counseling by using weak imperative sentences to deliver the information to the readers.

Suggestion in phatic advice is not really a suggestion which contains a problem solving. On the contrary, BlumKulka et al (1989) propose conventional strategy of advice giving which consists of suggestion formula and preparatory condition which are loaded by information leading to a problem solving. The kind of suggestion in phatic advice is more about a common statement which is not intended to solve one's problem.

The strategies to deliver phatic advice among Javanese youngsters are likely intended to minimize the potential risk of performing FTA. For instance, insinuating is used to replace warning. However, warning in phatic advice is not a strict warning. Yet, it is more likely a hint not to continue to do negative things. It is in relation to Non-conventional strategy of advice giving formulated by Blum-Kulka et al (1989) which consists of strong hints and soft hints. To this extent, this phenomenon is such a kind of the application of Javanese maxim Tepa Selira 'Being tolerant' in which one is expected to understand other's circumstances by being tolerant towards the negative things that someone has done.

In relation to General Strategy of Politeness (Leech, 2014), phatic advice giving is the realization of M2 maxim 'Give a low value to S's wants' which is related to directive speech act which is performed by applying tact maxim (Leech, 1983). In this case, speakers do not insist hearers to do what they want. In other words, phatic advice is not as strong as the real advice as it is not intended to help people to solve their problems. To this extent, M10 maxim 'Give a low value to S's feelings' is applied. Hence, speakers is expected to suppress their feelings if they do not agree with what hearers do. Therefore, phatic advice does not contain imperative force and performative force.

Apparently, phatic advice giving is a part of phatic communication which fulfills the goal of maintaining social relationship to tie a union (Malinowski 1923). However, phatic advice giving is not merely an effort to break the silence in order to fulfill the basic requirement of communication as defined by Coupland (2014). Yet, phatic advice giving is performed to maintain a social bond by expressing camaraderie. Therefore, phatic advice giving is an effort to show solidarity in order to create a strong social bond among the members of Javanese youngsters speech community.

\section{CONCLUSION}

The research successfully classifies the kinds of phatic advice into support, suggestion, and prohibition. Each kind is performed by using peculiar strategies in relation to Javanese politeness principles. The strategies of reassuring, complimenting, and encouraging in phatic support is the reflection of Rasa 'feeling'. In this case, Javanese youngsters express their sympathy and solidarity to their peer acquaintances by giving phatic advice which contains a support. However, the support does not contain any information which leads to a problem solving.

Next, phatic advice may contain suggestion which are delivered by stating coomon things and sharing common experiences. Therefore, the suggestion is phatic as it is just a common fact which does not contain a specific information. In this case, suggestion in phatic advice is given merely to show politeness and to express sympathy.

Prohibition is the least kind of phatic advice found among Javanese youngsters. It is mainly avoided as it potentially has a risk to perform FTA. Hence, prohibition is likely performed by uttering warning which contains a joke or insinuation. The strategies are used to reduce the potential risk of insulting others.

Apparently, the research proves that phatic advice plays an important role in Javanese youngsters speech community. The phaticity in advice giving mainly functions to maintain friendship and express solidarity in order to strengthen a social bond in a union. It fulfills the characteristics of phatic communion which is defined in the earlier theory of phatic speech act. However, phatic advice giving in Javanese culture is not found in other culture as advice giving is mainly a directive speech act which is intended to make hearers do something based on the instruction given by speakers.

\section{Acknowledgment}

This research was sponsored and financially supported by Indonesia Endowment Fund for Education Ministry of Finance, Republic of Indonesia (Lembaga Pengelola Dana Pendidikan Kementerian Keuangan Republik Indonesia LPDP Kemenkeu RI) under Grant No. PRJ4968/LPDP.3/2016.

\section{References}

Al-Shboul, Yasser, Marlyna Maros, and Mohamad Subakir Mohd Yasin. (2012). The appropriateness in advicegiving from a cross-cultural perspective. Arab World English Journal, 3(3), 106 - 122.

Blum-Kulka, S., House, J., \& Kasper, G. (1989).

Cross-cultural pragmatics: requests and apologies. Ablex Pub. Corp,

Coupland, J. (2014). Small talk. London: Routledge.

DeCapua, A, and J. F. Dunham. (2007). The pragmatics of advice giving: cross-cultural perspectives. Intercultural Pragmatics, 4(3). https://doi.org/10.1515/IP.2007.016

Djajasudarma, Fatimah. (2012). Wacana dan pragmatik. Bandung: Refika Aditama.

Farashaiyan, A. (2016). Pragmatic variations in giving advice in L2 by malaysian postgraduate students: the situational effects. English Language Teaching, 9, 179-191. 
Gunarwan, Asim. (2007). Pragmatik: teori dan kajian nusantara. Jakarta: Penerbit Universitas Atma Jaya.

Jumanto. (2011). Pragmatik: dunia linguistik tak selebar daun kelor. Semarang: WorldPro.

Jumanto, J. (2014). Phatic communication: how english native speakers create ties of union. American Journal of Linguistics, 9-16.

Kasper, G, and S Blum-Kulka. (1993). Interlanguage pragmatics: an introduction. Oxford: Oxford University Press.

Kreidler, C. W. (1998). Introducing english semantics. Hove: Psychology Press.

Leech, Geoffrey N. (1983). Principles of pragmatics. London: Longman, 1983.

- The pragmatics of politeness. (2014). Oxford: Oxford University Press.

Malinowski, B. (1923). The problem of meaning in primitive languages supplement. In CK Ogden and IA Richards (Eds.), The meaning of meaning, (296-336). New York: Harcourt Brace and World.

Patton, M. Q. (1980). Qualitative evaluation methods. Beverly Hills: Sage Publications.

Poerwadarminta, W. J. S. (1939). Baoesastra djawa. Jakarta: J. B. Wolters' Uitgevers-Maatschappij N. V. Groningen.

Rygg, K. (2016). Was malinowski norwegian? norwegian interpretations of phatic talk. Journal of Intercultural Communication, 40.

Santosa, R. (2017). Metode penelitian kualitatif kebahasaan. Surakarta: UNS Press.

Searle, J. R. (1969). Speech acts: an essay in the philosophy of language. Cambridge: Cambridge University Press.

Spradley, James P. (2016). Participant observation. Long Grove, Illinois: Waveland Press, Inc.

Subroto, H. D. Edi. (2008). Pragmatik dan beberapa segi metode penelitiannya. In Katharina Endriati Soekamto (Ed.), Kelana bahana sang bahasawan (pp. 505-513). Jakarta: Penerbit Universitas Atma Jaya.

Tsai, M.H., and C Kinginger. (2014). Giving and receiving advice in computer-mediated peer response activities. CALICO Journal, 32(1), 82-112.

https://doi.org/10.1558/calico.v32i1.25959

Wierzbicka, A. (2009). Cross-cultural pragmatics, the semantics of human interaction (2nd ed. [with a new preface] 2003). Berlin: De Gruyter Mouton. 